\title{
Pemodelan Faktor Risiko Penyakit Campak pada Balita di Provinsi DKI Jakarta
}

\author{
Ayu Annisa Rahmah*, Itasia Dina Sulvianti*, Cici Suhaeni*, Bimandra Adiputra Djaafara ${ }^{\dagger}$ \\ *Departemen Statistika Institut Pertanian Bogor \\ ${ }^{\dagger}$ Eijkman-Oxford Clinical Research Unit Jakarta
}

\begin{abstract}
Abstrak-Measles is one of the infectious caused by virus. The disease is easily transmitted and has become one of the main causes of child mortality especially toddlers. In 2016, Jakarta experienced the highest measles case in the last ten years and found the difference in the number of measles cases in each sub-district of Jakarta. This can be caused by the existence of effect of spatial location i.e. spatial heterogeneity. Geographically weighted regression (GWR) is a method that can be applied to address the presence of spatial heterogeneity in the process of developing the model. In this study, the weighting function used was the Gaussian kernel. The modelling process generated 42 local models at sub-district level. Explanatory variables that influence the incidence rate of measles in toddlers $(Y)$ signicantly are the percentage of immunization coverage measles (X1), the total annual rainfall (X4), and the percentage of the number of toddlers (X5). In this study, the GWR model is better than multiple linear regression model which were indicated by higher value of $R^{2}$ and smaller value of AIC.
\end{abstract}

Kata kunci-fungsi kernel Gaussian; heterogenitas spasial; incidence rate campak; regresi terboboti geografis

\section{PENDAHULUAN}

\section{A. Latar Belakang}

Measles atau biasa dikenal di Indonesia sebagai campak merupakan salah satu penyakit infeksi yang paling mudah menular (WHO, 2017). Berdasarkan data WHO, campak telah menyebabkan 2.6 juta kematian di seluruh dunia pada tahun 1980. Angka tersebut sebagian besar berasal dari anak-anak berusia di bawah lima tahun. Sedangkan di Indonesia dari tahun 2006 sampai 2016 diperkirakan terdapat 176944 kasus campak di Indonesia. Sedangkan di Provinsi DKI Jakarta tahun 2016, banyaknya kasus penderita campak tertinggi berturut-turut ditempati oleh Jakarta Timur dengan 803 kasus, Jakarta Barat sebanyak 792 kasus, Jakarta Selatan sebanyak 543 kasus, Jakarta Utara sebanyak 509 kasus, Jakarta Pusat sebanyak 464 kasus, dan Kepulauan Seribu sebanyak 1 kasus.

Penyakit campak dapat disebabkan oleh beberapa faktor risiko. Menurut Abdullatif (2012), risiko penyakit campak dapat disebabkan oleh banyaknya penduduk miskin, kepadatan penduduk, cakupan imunisasi campak, temperatur, curah hujan dan kelembapan. Sedangkan menurut WHO (2017), risiko penyakit campak dapat disebabkan oleh jumlah fasilitas kesehatan dan jumlah tenaga kesehatan. Pada kasus campak di DKI Jakarta tahun 2016, nampak terlihat adanya perbedaan banyaknya penderita campak di setiap kota/kabupaten DKI Jakarta. Hal ini dapat dimungkinkan oleh adanya faktor lokasi, dimana di setiap kabupaten/kota memiliki karakteristik geogras, sosial budaya, dan ekonomi yang berbeda sehingga membuat faktor-faktor risiko yang berkaitan dengan kasus penderita campak kabupaten/kota di suatu daerah berbeda dengan daerah lainnya. Faktor lokasi ini dapat disebut dengan efek spasial, yaitu heterogenitas spasial.

Selain itu, pengamatan di daerah tertentu dapat dipengaruhi oleh pengamatan di daerah sekitarnya. Hal ini sesuai dengan Hukum I Tobler yang menyatakan "Segala sesuatu saling berhubungan satu dengan yang lainnya, tetapi sesuatu yang dekat lebih mempunyai pengaruh daripada sesuatu yang jauh" (Anselin, 1988). Oleh karena itu, daerah dengan tingkat penderita campak yang tinggi cenderung dikelilingi oleh daerah dengan tingkat penderita campak yang cukup tinggi pula. Hukum I Tobler berkaitan dengan salah satu pengaruh efek spasial, yaitu ketergantungan spasial.

Pengidentifikasian faktor-faktor yang berpengaruh terhadap kasus penderita campak di DKI 
Jakarta dapat dilakukan dengan pemodelan. Hal ini dapat dilakukan dengan analisis regresi, yaitu suatu metode untuk memodelkan hubungan antara peubah respon dengan peubah penjelas. Namun pada kenyataannya terkadang kondisi banyaknya penderita campak pada suatu lokasi tidak selalu sama dengan lokasi yang lain. Kondisi ini mungkin dipengaruhi oleh efek spasial. Jika terdapat heterogenitas spasial, maka asumsi kehomogenan ragam sisaan menjadi sulit terpenuhi, sehingga model yang dapat digunakan adalah model regresi terboboti geografis (RTG). Jika terdapat efek spasial yaitu ketergantungan spasial, maka asumsi kebebasan sisaan menjadi sulit terpenuhi, sehingga model yang dapat digunakan adalah model regresi spasial.

\section{B. Tujuan}

Tujuan dari penelitian ini adalah memodelkan incidence rate penyakit campak pada balita di DKI Jakarta tahun 2016 untuk melihat faktor-faktor risiko yang berpengaruh signifikan terhadap kejadian campak pada balita di DKI Jakarta.

\section{TINJAUAN PUSTAKA}

\section{A. Regresi Linier Berganda}

Regresi linier berganda merupakan perluasan dari model regresi sederhana. Model ini digunakan untuk mengevaluasi hubungan antara peubah respon dengan beberapa peubah penjelas. Menurut Draper and Smith (1992), model regresi berganda dapat dinyatakan sebagai berikut:

$$
\mathbf{y}=\mathbf{X B}+\mathbf{e}
$$

dengan $\mathbf{y}$ adalah vektor amatan peubah respon yang berukuran $n \times 1$, $\mathbf{X}$ adalah matriks peubah penjelas berukuran $n \times(k+1)$, B adalah vektor parameter regresi berukuran $(k+1) \times 1$, e adalah vektor sisaan berukuran $n \times 1$, dengan $n$ adalah banyaknya amatan dan $k$ adalah banyaknya peubah penjelas.

Persamaan pendugaan parameter pada regresi berganda dengan menggunakan metode kuadrat terkecil (MKT) dapat dinyatakan sebagai berikut:

$$
\hat{\mathbf{B}}=\left(\mathbf{X}^{\prime} \mathbf{X}\right)^{-1} \mathbf{X}^{\prime} \mathbf{y}
$$

Menurut Gujarati (2004), metode regresi linier berganda memiliki asumsi-asumsi yang harus dipenuhi yaitu sisaan menyebar normal, ragam sisaan homogen, sisaan saling bebas, dan tidak ada multikolinieritas.

\section{B. Uji Efek Spasial}

Pengujian efek spasial berhubungan dengan keheterogenan spasial dan ketergantungan spasial. Heterogenitas spasial atau keragaman spasial adalah perbedaan karakteristik lingkungan dan geografis antar lokasi pengamatan sehingga masing-masing pengamatan kemungkinan memiliki variasi yang berbeda atau terdapat perbedaan pengaruh peubah penjelas terhadap peubah respon untuk setiap lokasi pengamatan. Menurut Anselin (1988), untuk mengidentifikasi adanya keragaman spasial dapat dilakukan dengan uji Breusch-Pagan. Hipotesis pada uji Breusch-Pagan adalah :

$H_{0}: \sigma^{2}\left(u_{i}, v_{i}\right)=\ldots=\sigma^{2}\left(u_{n}, v_{n}\right)=\sigma^{2}$

$H_{1}$ : minimal ada satu $\sigma^{2}\left(u_{i}, v_{i}\right) \neq \sigma^{2}\left(u_{j}, v_{j}\right)$ untuk $i \neq j$

Statistik uji:

$$
B P=\left(\frac{1}{2}\right) \mathbf{h}^{\prime} \mathbf{z}\left(\mathbf{z}^{\prime} \mathbf{z}\right)^{-1} \mathbf{z}^{\prime} \mathbf{h}
$$

dengan,

$$
\mathbf{h}=\left(\frac{e_{i}^{2}}{\sigma^{2}}-1\right)
$$

$\mathbf{z}$ adalah vektor amatan peubah respon y yang berukuran $(n \times 1)$ dan sudah dibakukan untuk pengamatan ke- $i$. Sedangkan $e_{i}^{2}$ adalah kuadrat sisaan untuk pengamatan ke- $i$ dan $\sigma^{2}$ merupakan ragam dari $e_{i}$. Kriteria uji pada uji ini adalah tolak H0 jika nilai BP lebih besar dari $\chi_{(k)}^{2}$ dengan $\chi_{(k)}^{2}$ merupakan nilai tabel khi-kuadrat dengan derajat bebas $k$.

Ketergantungan spasial atau autokorelasi spasial didefinisikan sebagai penilaian korelasi antar pengamatan/lokasi pada suatu variabel. Autokorelasi spasial melihat kemiripan antara satu lokasi dengan lokasi lainnya berdasarkan kondisi atau fenomena yang terjadi pada lokasi tersebut (Lee and Wong, 2001). Indeks Moran merupakan salah satu metode yang sering digunakan untuk mengukur autokorelasi spasial. Perhitungan autokorelasi spasial menggunakan Indeks Moran sebagai berikut :

$$
I=\frac{n \sum_{i=1}^{n} \sum_{j=1}^{n} w_{i j}\left(e_{i}-\bar{e}\right)\left(e_{j}-\bar{e}\right)}{\sum_{i=1}^{n} \sum_{j=1}^{n} w_{i j} \sum_{i=1}^{n}\left(e_{i}-\bar{e}\right)^{2}}
$$


Keterangan :

I : Indeks moran

$n \quad$ : Banyaknya pengamatan

$\bar{e} \quad$ : Rata-rata nilai sisaan

$e_{i} \quad$ : Nilai sisaan pada lokasi ke- $i$

$e_{j} \quad:$ Nilai sisaan pada lokasi ke-j

$w_{i j} \quad$ : Elemen matriks pembobot terstandarisasi antara lokasi ke- $i$ dan ke- $j$

Pada penelitian ini, dalam menghitung $w_{i j}$ yang sudah terstandarisasi pada Indeks Moran dapat menggunakan pembobotan kebertetanggaan sisi dan sudut (queen contiguity). Matriks pembobot ini memberi nilai 1 untuk seluruh wilayah yang bersinggungan dengan wilayah pengamatan dan memberi nilai 0 untuk wilayah lainnya. Formula matriks pembobot queen contiguity yang sudah terstandarisasi dapat dinyatakan sebagai berikut:

$$
w_{i j}=\frac{c_{i j}}{\sum_{j=1}^{n} c_{i j}}
$$

dengan $c_{i j}$ adalah elemen matriks kebertetanggaan baris ke- $i$ dan kolom ke- $j$.

Rentang nilai dari Indeks Moran dengan matriks pembobot terstandarisasi berkisar antara -1 sampai 1. Nilai Indeks Moran bernilai nol mengindikasikan tidak bergerombol atau berpola acak, nilai Indeks Moran berkisar $0<\mathrm{I} \leq 1$ mengindikasikan autokorelasi spasial positif, dan nilai Indeks Moran berkisar $-1 \leq \mathrm{I}<0$ mengindikasikan autokorelasi spasial negatif. Kemudian, uji signifikansi Indeks Moran dapat dituliskan dengan hipotesis sebagai berikut:

$H_{0}: \mathrm{I}=0$

$H_{1}: I \neq 0$

Statistik uji :

$$
Z(I)=\frac{I-E(I))}{\sqrt{\operatorname{var}(I)}}
$$

dengan,

$$
\begin{gathered}
E(I)=-\frac{1}{n-1} \\
\operatorname{Var}(I)=\frac{n^{2} S_{1}-n^{2} S_{2}+3 S_{0}^{2}}{\left(n^{2}-1\right) S_{0}^{2}}-[E(I)]^{2}
\end{gathered}
$$

$$
\begin{gathered}
S_{0}=\sum_{i=1}^{n} \sum_{j=1}^{n} W_{i j} \\
S_{1}=\frac{1}{2} \sum_{i=1}^{n} \sum_{j=1}^{n}\left(W_{i j}+W_{j i}\right)^{2} \\
S_{2}=\sum_{i=1}^{n}\left(\sum_{j=1}^{n} W_{i j}+\sum_{j=1}^{n} W_{j i}\right)^{2}
\end{gathered}
$$

Kriteria uji pada uji ini adalah tolak H0 jika nilai mutlak Z(I) lebih besar dari $Z_{\alpha / 2}$ dengan $Z_{\alpha / 2}$ merupakan nilai $Z$ tabel dengan parameter $\alpha / 2$ atau nilai-p lebih kecil dari $\alpha$ dengan $\alpha$ merupakan taraf nyata.

\section{Regresi Terboboti Geografis}

Regresi terboboti geografis (RTG) merupakan salah satu pendekatan titik yang efektif untuk mengatasi data yang memiliki heterogenitas spasial. Pada dasarnya, model RTG membawa kerangka model regresi linier klasik menjadi model regresi terboboti yang bersifat lokal (Fotheringham et al., 2002). Oleh karena itu, nilai parameter model RTG berbeda pada setiap lokasi karena dihitung pada setiap lokasi pengamatan. Secara umum model RTG dapat dituliskam sebagai berikut:

$$
y_{i}=\beta_{0}\left(u_{i}, v_{i}\right)+\sum_{l=1}^{k} \beta_{l}\left(u_{i}, v_{i}\right) x_{i l}+\varepsilon_{i}
$$

Keterangan :

$y_{i} \quad$ : Nilai amatan peubah respon ke- $i$

$\beta_{0}\left(u_{i}, v_{i}\right)$ : Nilai intersep pada pengamatan ke- $i$

$\beta_{l}\left(u_{i}, v_{i}\right)$ : Nilai parameter ke- $l$ dari pengamatan ke- $i$

$x_{i l} \quad:$ Nilai amatan peubah penjelas ke- $l$ pada pengamatan ke- $i$

$\varepsilon_{i} \quad:$ Nilai sisaan regresi antara peubah penjelas dengan peubah respon pengamatan ke- $i$ dengan $i=1,2, . ., n$

$\left(u_{i}, v_{i}\right)$ : Menyatakan koordinat lokasi (bujur, lintang) pengamatan ke- $i$

Persamaan pendugaan parameter RTG dengan metode kuadrat terkecil terboboti (Weighted Least Square) dapat dinyatakan sebagai berikut:

$$
\hat{\mathbf{B}}_{(i)}=\left(\mathbf{X}^{\prime} \mathbf{W}_{(i)} \mathbf{X}\right)^{-1} \mathbf{X}^{\prime} \mathbf{W}_{(i)} \mathbf{y}
$$

dengan $\mathbf{W}_{(i)}$ adalah matriks diagonal berukuran ( $n$ $\times n)$ yang merupakan matriks pembobot spasial 
lokasi ke- $i$ dengan nilai unsur-unsur diagonalnya ditentukan oleh jarak antar lokasi pengamatan ke- $i$ dengan lokasi lainnya (lokasi ke- $j$ ) dan unsur selain diagonalnya bernilai nol.

\section{Pembobot Model Regresi Terboboti Geografis}

Pada RTG, fungsi pembobot memiliki peran yang sangat penting karena mewakili letak data pengamatan satu dengan pengamatan lainnya. Pembobot RTG dapat ditentukan dengan menggunakan beberapa fungsi, salah satunya fungsi kernel Gaussian. Fungsi tersebut dinyatakan dengan:

$$
W_{i j}=\exp \left(-\frac{1}{2}\left(\frac{d_{i j}}{b}\right)^{2}\right)
$$

$d_{i j}$ merupakan jarak Euclidean antara lokasi $\left(u_{i}, v_{i}\right)$ ke lokasi $\left(u_{j}, v_{j}\right)$ dengan persamaan sebagai berikut:

$$
d_{i j}=\sqrt{\left(u_{i}-u_{j}\right)^{2}+\left(v_{i}-v_{j}\right)^{2}}
$$

b adalah bandwidth atau lebar jendela yang dianalogikan sebagai radius (b) suatu lingkaran, sehingga sebuah titik lokasi pengamatan yang berada dalam radius lingkaran masih dianggap berpengaruh dalam membentuk parameter di titik lokasi pengamatan ke-i. Salah satu teknik untuk mendapatkan nilai lebar jendela optimum adalah dengan teknik validasi silang (cross validation). Validasi silang dapat dirumuskan sebagai berikut:

$$
\sum_{i=1}^{n}\left[y_{i}-y_{\neq i}(b)\right]^{2}
$$

$y_{\neq i}(b)$ adalah nilai dugaan $y_{i}$ dengan nilai pengamatan lokasi ke- $i$ dihilangkan dari proses pendugaan. Nilai lebar jendela optimum diperoleh saat $\mathrm{CV}$ bernilai minimum.

\section{E. Uji Signifikansi Parameter RTG}

Pengujian parameter secara parsial dilakukan untuk mengetahui faktor-faktor yang signifikan atau memengaruhi peubah responnya pada tiap lokasi. Hipotesis yang digunakan adalah sebagai berikut : $H_{0}: \beta_{l}\left(u_{i}, v_{i}\right)=0$

$H_{1}: \beta_{l}\left(u_{i}, v_{i}\right) \neq 0$, untuk $l=1,2, . ., k ; i=1,2, . ., n$

Statistik uji:

$$
t_{l}\left(u_{i}, v_{i}\right)=\frac{\hat{\beta}_{l}\left(u_{i}, v_{i}\right)}{S E\left(\hat{\beta}_{l}\left(u_{i}, v_{i}\right)\right)}
$$

dengan $\hat{\beta}_{l}\left(u_{i}, v_{i}\right)=\mathbf{C y}, S E\left(\hat{\beta}_{l}\left(u_{i}, v_{i}\right)\right)=\sqrt{c_{l l} \sigma^{2}}, c_{l l}$ adalah unsur diagonal matriks $\mathbf{C} \mathbf{C}^{\prime}$ dimana matriks $\mathbf{C}=\left(\mathbf{X}^{\prime} \mathbf{W}\left(u_{i}, v_{i}\right) \mathbf{X}\right)^{-1} \mathbf{X}^{\prime} \mathbf{W}\left(u_{i}, v_{i}\right) . \sigma^{2}$ adalah nilai kuadrat tengah galat model RTG, dan $v$ adalah derajat bebas $(n-k-1)$. Kriteria uji pada uji ini adalah tolak H0 jika nilai mutlak $t_{l}\left(u_{i}, v_{i}\right)$ lebih besar dari $t_{v, \alpha / 2}$ dengan $t_{v, \alpha / 2}$ merupakan nilai t-tabel dengan derajat bebas $\mathrm{v}$.

\section{F. Pemilihan Model Terbaik}

Analisis ragam dapat digunakan untuk menguji apakah terdapat perbedaan yang signifikan antara model RTG dengan model regresi linier berganda. Menurut Brunsdon et al. (1999), pengujian ini dapat dituliskan dengan hipotesis sebagai berikut:

$H_{0}: \beta_{l}=\beta_{l}\left(u_{i}, v_{i}\right)$

$H_{1}: \beta_{l} \neq \beta_{l}\left(u_{i}, v_{i}\right)$

Statistik uji:

$$
F_{h i t}=\frac{\left(J K G_{M K T}-J K G_{R T G}\right) / v}{J K G_{R T G} / d_{1}}
$$

dengan $J K G_{M K T}$ adalah jumlah kuadrat galat dari model regresi linier berganda, $J K G_{R T G}$ adalah jumlah kuadrat galat dari model RTG. Nilai $F_{\text {hit }}$ akan mendekati sebaran-F dengan derajat bebas pembilang $v^{2} / v^{*}$ dan derajat bebas penyebut $d_{1}^{2} / d_{2}$, dengan $d_{i}=\operatorname{tr}\left[\left(\mathbf{I}-\mathbf{S}_{\mathbf{1}}\right)^{\prime}(\mathbf{I}-\right.$ $\left.\left.\mathbf{S}_{\mathbf{1}}\right)\right]^{i}, \boldsymbol{i}=1,2$ dimana $\mathbf{S}_{\mathbf{0}}=\mathbf{X}\left(\mathbf{X}^{\prime} \mathbf{X}\right)^{-1} \mathbf{X}^{\prime}, \mathbf{S}_{\mathbf{1}}=$ $\mathbf{X}\left(\mathbf{X}^{\prime} \mathbf{W}\left(u_{1}, v_{1}\right) \mathbf{X}\right)^{-1} \mathbf{X}^{\prime} \mathbf{W}\left(u_{1}, v_{1}\right)$, dengan $\mathbf{S}_{\mathbf{0}}$ dan $\mathbf{S}_{\mathbf{1}}$ merupakan matriks hat dari regresi linier berganda dan RTG. Nilai $v=\operatorname{tr}\left(\mathbf{R}_{\mathbf{0}}-\mathbf{R}_{\mathbf{1}}\right)$ dan $v^{*}=$ $\operatorname{tr}\left[\left(\mathbf{R}_{\mathbf{0}}-\mathbf{R}_{\mathbf{1}}\right)^{2}\right]$ dengan $\mathbf{R}_{\mathbf{0}}=\operatorname{tr}\left[\left(\mathbf{I}-\mathbf{S}_{\mathbf{0}}\right)^{\prime}\left(\mathbf{I}-\mathbf{S}_{\mathbf{0}}\right)\right]$ dan $\mathbf{R}_{\mathbf{1}}=\operatorname{tr}\left[\left(\mathbf{I}-\mathbf{S}_{\mathbf{1}}\right)^{\prime}\left(\mathbf{I}-\mathbf{S}_{\mathbf{1}}\right)\right]$. Kriteria uji pada analisis ragam adalah tolak $\mathrm{H} 0$ jika nilai $F_{\text {hit }}$ lebih besar dari $F_{\alpha\left(v_{1}^{2} / v_{2}, d_{1}^{2} / d_{2}\right)}$.

Pemilihan model terbaik antara regresi linier berganda dengan RTG dapat dilakukan dengan dua cara, yaitu dengan melihat nilai $R^{2}$ yang terbesar dan nilai Akaike Information Criterion (AIC) yang terkecil. Menurut Fotheringham et al. (2002) persamaan AIC dapat dituliskan sebagai berikut:

$$
A I C=2 n \log _{e}(\hat{\sigma})+n \log _{e}(2 \pi)+n+\operatorname{tr}(S)
$$

dengan $\hat{\sigma}=\sqrt{K T G}, K T G$ adalah kuadrat tengah galat, $n$ adalah jumlah amatan, dan $\operatorname{tr}(S)$ adalah teras dari matriks proyeksi yang mentransformasi vektor $\hat{y}$ dari vektor $y$ pengamatan $(\hat{y}=S y)$. 
Sedangkan persaamaan $R^{2}$ dapat dituliskan sebagai berikut :

$$
R^{2}=1-\frac{J K G}{J K T}
$$

dengan $J K G=\sum_{i=1}^{n}\left(y_{i}-\hat{y}_{i}\right)^{2}, J K T=\sum_{i=1}^{n}\left(y_{i}-\right.$ $\left.\bar{y}_{i}\right)^{2}$, dimana $y_{i}$ adalah nilai amatan peubah respon ke- $i, \hat{y}_{i}$ adalah nilai dugaan peubah respon ke- $i$, dan $\bar{y}$ adalah rata-rata peubah respon.

\section{METODOLOGI}

\section{A. Data}

Data yang digunakan dalam penelitian ini adalah data sekunder yang diperoleh dari website Departemen Surveilens dan Imunisasi Dinas Kesehatan Provinsi DKI Jakarta, website Pemerintah Provinsi DKI Jakarta, website International Research Institute for Climate and Society Columbia University, dan website Badan Pusat Statistik (BPS) di masingmasing kota Provinsi DKI Jakarta pada tahun 2016. Adapun amatan yang digunakan dalam penelitian ini ada sebanyak 42 kecamatan di Provinsi DKI Jakarta. Peubah yang digunakan terdapat pada Tabel 1.

Tabel I

DAFTAR PEUBAH YANG DIGUNAKAN

\begin{tabular}{clc}
\hline Peubah & \multicolumn{1}{c}{ Keterangan } & Satuan \\
\hline$Y$ & $\begin{array}{l}\text { Incidence rate campak balita per 100 000 } \\
\text { balita }\end{array}$ & orang \\
$X_{1}$ & $\begin{array}{l}\text { Persentase cakupan imunisasi campak pada } \\
\text { tahun 2016 }\end{array}$ & $\%$ \\
$X_{2}$ & Kepadatan penduduk & orang $/ \mathrm{km}^{2}$ \\
$X_{3}$ & $\begin{array}{l}\text { Jumlah fasilitas kesehatan per 100 000 pen- } \\
\text { duduk }\end{array}$ & unit \\
$X_{4}$ & $\begin{array}{l}\text { Total curah hujan tahunan } \\
X_{5}\end{array}$ & Persentase banyaknya balita \\
\hline
\end{tabular}

\section{B. Prosedur Analisis Data}

Tahapan analisis data yang dilakukan dalam penelitian ini adalah sebagai berikut:

1) Melakukan eksplorasi data pada keenam peubah yang digunakan untuk melihat karakteristik data secara umum.

2) Melakukan pendugaan parameter model regresi linier berganda dengan metode kuadrat terkecil dan memilih peubah penjelas yang berpengaruh.
3) Melakukan pemeriksaan asumsi dari model regresi linier berganda.

a) Pemeriksaan asumsi multikolinieritas pada peubah penjelas dengan melihat nilai Variance Inflation Factor (VIF).

b) Pemeriksaan asumsi kenormalan sisaan dengan uji Kolmogorov-Smirnov.

c) Pemeriksaan asumsi kebebasan sisaan dengan uji Runs-Test.

d) Pemeriksaan asumsi kehomogenan ragam sisaan dengan uji Gletjser.

e) Jika keempat asumsi model regresi linier berganda terpenuhi maka pemodelan yang digunakan adalah pemodelan regresi linier berganda, sedangkan jika ada salah satu asumsi yaitu kehomogenan ragam sisaan atau kebebasan sisaan tidak terpenuhi maka lanjut ke langkah (4).

4) Melakukan uji efek spasial pada sisaan model regresi linier berganda dengan uji BreuschPagan untuk melihat keheterogenan spasial dan uji Indeks Moran untuk melihat ketergantungan spasial. Jika Breusch-Pagan terima $\mathrm{HO}$ dan Indeks Moran tolak H0 maka pemodelan yang digunakan adalah pemodelan regresi spasial. Jika Breusch-Pagan tolak H0 dan Indeks Moran terima H0 dapat melanjutkan ke langkah (5).

5) Melakukan analisis regresi terboboti geografis.

a) Menentukan titik koordinat (lintang, bujur) tiap kecamatan.

b) Menghitung jarak Euclidean antar kecamatan.

c) Menentukan bandwidth optimum berdasarkan $\mathrm{CV}$ minimum.

d) Menghitung matriks pembobot tiap kecamatan dengan fungsi kernel Gaussian.

e) Melakukan pendugaan parameter regresi menggunakan bandwidth optimum.

f) Melakukan uji signifikansi parameter RTG yang didapat.

6) Membandingkan model regresi linier berganda dengan model RTG

a) Melakukan uji $\mathrm{F}$ untuk mengetahui adanya perbedaan yang signifikan antara model regresi linier berganda dengan 
model RTG.

b) Memilih model terbaik dengan menggunakan $R^{2}$ dan AIC. Model dengan nilai $R^{2}$ terbesar dan nilai AIC terkecil adalah model yang dipilih.

Software yang digunakan dalam penelitian ini adalah QGIS 2.81 dan R 3.5.0.

\section{HASIL DAN PEMBAHASAN}

\section{A. Eksplorasi Data}

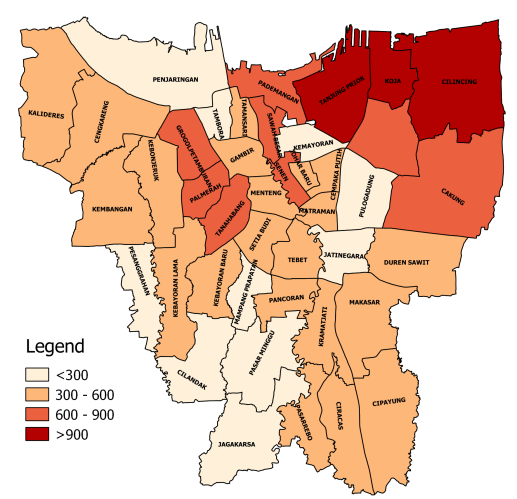

Gambar 1. Peta sebaran IR campak pada balita di DKI Jakarta

Pendeskripsian sebaran IR campak pada balita di Provinsi DKI Jakarta dilakukan pengelompokan berdasarkan jurnal Kidd et al. (2012). Pada Gambar 1 terlihat bahwa penyebaran penderita penyakit campak pada balita terbagi menjadi empat kelompok. Hampir $50 \%$ atau sekitar 21 kecamatan penderita campak pada balita berada di kelompok kedua yaitu berkisar 300-600 kasus per 100000 balita. Kemudian, terdapat tiga kecamatan yang memiliki nilai IR campak tertinggi yaitu Kecamatan Tanjung Priok, Koja, dan Cilincing yang berada dikisar lebih dari 900 kasus per 100000 balita. Kecamatan Tanjung Priok memiliki nilai IR campak paling tinggi diantara dua kecamatan tersebut dengan nilai sebesar 2233.765 atau sebanyak 2234 kasus balita terkena penyakit campak per 100000 balita selama tahun 2016. Hal ini dikarenakan di Kecamatan Tanjung Priok memiliki nilai persentase cakupan imunisasi campak yang masih di bawah dari target Indonesia (95\%) yaitu sebesar $87.44 \%$. Kecamatan di Provinsi DKI Jakarta memiliki IR campak yang beragam atau berbeda-beda. Selain itu, gambar tersebut juga menunjukkan pola yang cenderung acak atau tidak bergerombol. Adanya keragaman dan pola acak ini dimungkinkan dipengaruhi oleh faktor lokasi.

\section{B. Pemodelan dengan Regresi Linier Berganda}

Analisis regresi linier berganda dilakukan guna untuk mendapatkan peubah yang signifikan berpengaruh secara linier terhadap IR campak pada balita. Peubah dikatakan signifikan jika nilai-p lebih kecil dari taraf nyata 0.05 dengan kata lain tolak H0. Peubah penjelas yang berpengaruh signifikan terhadap IR campak pada balita adalah peubah persentase cakupan imunisasi campak (X1), total curah hujan tahunan (X4), dan persentase banyaknya balita (X5). Kemudian peubah-peubah penjelas tersebut dipilih untuk digunakan analisis regresi linier berganda kembali, sehingga dari analisis tersebut mendapatkan model persamaan garis untuk dugaan peubah respon sebagai berikut :

$$
\begin{aligned}
\hat{y}= & 4823.2228-46.5053 X_{1}-0.2926 X_{4} \\
& +128.6549 X_{5}
\end{aligned}
$$

Pemeriksaan asumsi model regresi linier berganda dilakukan dengan beberapa uji formal. Pemeriksaan asumsi tidak adanya multikolinieritas dapat dilihat dari nilai VIF. Nilai VIF ketiga peubah secara berturut-turut adalah 1.1534, 1.2188, 1.1967. Nilai VIF dari ketiga peubah penjelas tersebut semuanya lebih kecil dari 10, sehingga dapat dikatakan tidak ada multikolieritas.

Selanjutnya, pemeriksaan asumsi kenormalan sisaan dapat dilakukan dengan menggunakan uji Kolmogorv-Smirnov. Hasil dari uji KolmogorvSmirnov didapatkan nilai-p (0.150) lebih besar dari taraf nyata 0.05 maka diperoleh keputusan tidak tolak H0 yang artinya sisaan menyebar normal.

Selanjutnya, pemeriksaan asumsi kebebasan sisaan dapat dilakukan dengan menggunakan uji Runs-Test. Hasil dari uji Runs-Test didapatkan nilai-p (0.214) lebih besar dari taraf nyata 0.05 maka diperoleh keputusan tidak tolak $\mathrm{H} 0$ yang artinya antar sisaan saling bebas.

Pemeriksaan asumsi terakhir adalah kehomogenan ragam sisaan dapat dilakukan dengan menggunakan uji Glejser. Hasil dari uji Glejser didapatkan nilai-p (0.004) lebih kecil dari taraf nyata 0.05 maka diperoleh keputusan tolak $\mathrm{H} 0$ yang artinya ragam sisaan heterogen. 


\section{Uji Efek Spasial}

Hasil dari uji Breusch-Pagan didapatkan sebesar (13.089) dengan nilai-p (0.004). Nilai-p tersebut lebih kecil dari taraf nyata 0.05 sehingga tolak H0. Maka dapat disimpulkan bahwa sisaan pada model regresi linier berganda antara IR campak balita dengan peubah-peubah penjelasnya memiliki keragaman spasial. Kemudian, nilai Indeks Moran yang didapatkan sebesar -0.098 dengan nilai-p (0.432). Nilai-p tersebut lebih besar dari taraf nyata 0.05 sehingga terima $\mathrm{H} 0$ yang artinya tidak ada ketergantungan spasial pada IR campak pada baita. Tidak adanya ketergantungan spasial meingindikasikan IR campak pada balita disatu kecamatan tidak bergantung dengan kecamatan lainnya di Provinsi DKI Jakarta. Adanya keragaman spasial dan tidak adanya ketergantungan spasial pada kasus ini tidak bisa menggunakan pemodelan dengan regresi linier berganda. Namun dapat diatasi dengan pemodelan regresi terboboti geografis (RTG).

\section{Pemodelan dengan Regresi Terboboti Geografis}

Pada RTG, nilai penduga parameter pada setiap lokasi berbeda. Hal ini terjadi karena setiap kecamatan dipengaruhi oleh kondisi relatif kecamatan di sekelilingnya. Hasil penduga parameter dengan RTG pada IR campak pada balita di DKI Jakarta berbeda-beda di tiap peubah. Peubah persentase cakupan imunisasi campak (X1) dan total curah hujan tahunan (X4) memiliki penduga parameter yang negatif di tiap kecamatan. Berbeda dengan peubah persentase banyaknya balita (X5) yang memberikan kontribusi yang positif maupun negatif.

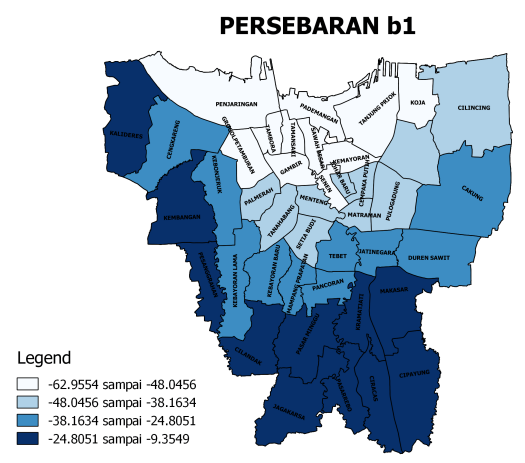

Gambar 2. Peta keragaman spasial penduga koefisien persentase cakupan imunisasi campak (X1)

Penggambaran sebaran penduga parameter persentase cakupan imunisasi campak (X1) di DKI
Jakarta dapat dilihat pada Gambar 2. Nilai koefisien penduga parameter cakupan imunisasi campak (X1) pada semua kecamatan bertanda negatif, yang artinya meningkatnya persentase cakupan imunisasi campak akan mengurangi IR campak per 100000 balita. Secara kasat mata, terlihat penyebaran nilai koefisien penduga parameter cakupan imunisasi campak (X1) di DKI Jakarta dari utara ke selatan semakin besar, sehingga semakin ke selatan daerah di DKI Jakarta memiliki pengaruh semakin kecil terhadap besarnya penurunan IR campak pada balita.

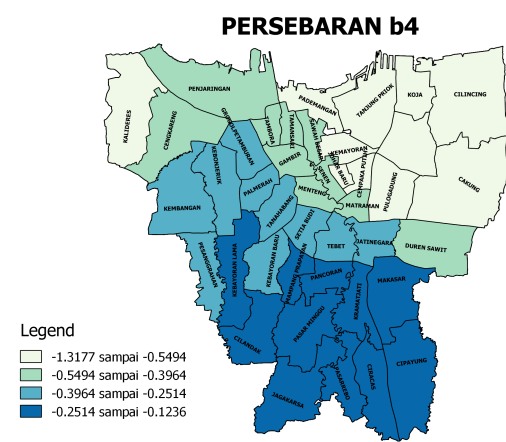

Gambar 3. Peta keragaman spasial penduga koefisien total curah hujan tahunan $(\mathrm{X} 4)$

Penggambaran sebaran penduga parameter total curah hujan tahunan di DKI Jakarta dapat dilihat pada Gambar 3. Nilai koefisien penduga parameter total curah hujan tahunan (X4) pada semua kecamatan bertanda negatif, yang artinya meningkatnya curah hujan akan mengurangi IR campak per 100 000 balita. Secara kasat mata terlihat penyebaran nilai koefisien penduga parameter total curah hujan tahunan (X4) di DKI Jakarta dari utara ke selatan semakin besar, sehingga semakin ke selatan daerah di DKI Jakarta memiliki pengaruh semakin kecil terhadap besarnya penurunan IR campak pada balita.

Penggambaran sebaran penduga parameter persentase banyaknya balita di DKI Jakarta dapat dilihat pada Gambar 4. Nilai koefisien penduga parameter persentase banyaknya balita (X5) di setiap kecamatan DKI Jakarta memiliki nilai yang bertanda positif dan negatif. Tanda positif ini menandakan bahwa jika semakin tinggi persentase banyaknya balita maka nilai IR campak akan semakin besar atau dengan kata lain meningkatnya persentase banyaknya balita akan meningkatkan IR 


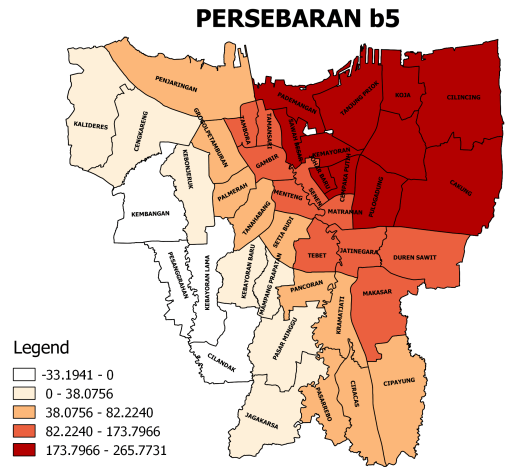

Gambar 4. Peta keragaman spasial penduga koefisien persentase banyaknya balita $1(\mathrm{X} 5)$

campak per 100000 balita. Hubungan positif antara peubah X5 dengan IR campak pada balita terjadi pada 38 kecamatan, sedangkan empat kecamatan sisanya memiliki hubungan negatif. Secara kasat mata terlihat penyebaran nilai koefisien penduga parameter persentase banyaknya balita (X5) di DKI Jakarta dari barat ke timur semakin besar, sehingga semakin ke timur daerah di DKI Jakarta memiliki pengaruh semakin besar terhadap besarnya peningkatan IR campak pada balita.

\section{E. Uji Signifikansi Parameter RTG}

Pengujian penduga koefisien parameter tiap peubah penjelas di setiap kecamatan Provinsi DKI Jakarta dilakukan untuk mengetahui peubah penjelas yang signifikan memengaruhi IR campak pada balita. Hal ini dilakukan karena pada model RTG tidak semua peubah (X1, X4, dan X5) berpengaruh di setiap kecamatan Provinsi DKI Jakarta.

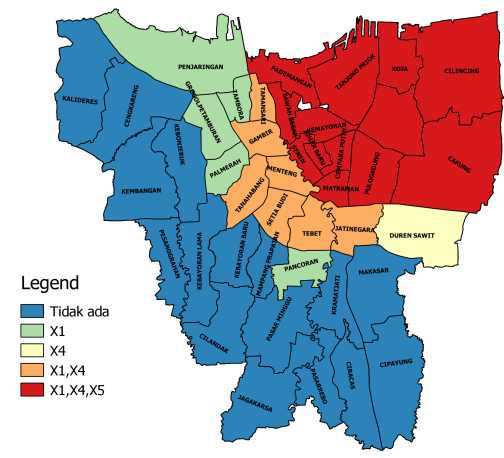

Gambar 5. Peta sebaran peubah penjelas yang signifikan terhadap Y

Berdasarkan Gambar 5, peubah penjelas yang berpengaruh terhadap IR campak pada balita di se- tiap kecamatan di DKI Jakarta membentuk 5 kelompok daerah. Pertama (yang berwarna biru), merupakan kelompok yang paling banyak anggotanya yaitu sebanyak enam belas kecamatan. Kelompok ini didominasi oleh daerah selatan dan barat DKI Jakarta. Kelompok ini, tidak ada peubah penjelas yang signifikan berpengaruh terhadap IR campak pada balita pada taraf nyata 0.05 . Kedua (yang berwarna hijau), merupakan kelompok yang beranggotakan sebanyak lima kecamatan dan hanya dipengaruhi oleh peubah persentase cakupan imunisasi campak (X1) pada taraf nyata 0.05 .

Selanjutnya, kelompok ketiga (yang berwarna kuning), merupakan kelompok yang hanya memiliki satu anggota, yaitu Duren Sawit dan hanya dipengaruhi oleh peubah total curah hujan tahunan (X4). Keempat (yang berwarna oranye), merupakan kelompok yang berada di daerah pusat DKI Jakarta dan dipengaruhi oleh peubah persentase cakupan imunisasi campak (X1) dan total curah hujan tahunan (X4) pada taraf nyata 0.05. Kelima (yang berwarna merah), merupakan kelompok yang memiliki anggota terbanyak kedua yaitu sebanyak tiga belas kecamatan. Kelompok ini, IR campak pada balita dipengaruhi oleh peubah persentase cakupan imunisasi campak (X1), total curah hujan tahunan (X4), dan persentase banyaknya balita (X5) pada taraf nyata 0.05 .

\section{F. Pemilihan Model Terbaik}

Pemilihan model terbaik antara regresi linier berganda dengan RTG dapat dilihat dari uji F, nilai AIC, dan $\mathrm{R}^{2}$. Uji F dilakukan secara global dengan menggunakan uji F Brudnsdson, Foterringham and Chartlon. Hasil yang diperoleh dari F-hitung adalah 4.579 lebih besar dari tabel $\left.F_{(} 0.05(6,34)\right)$ sebesar 2.649 maka diperoleh keputusan tolak H0. Artinya terdapat perbedaan yang signifikan antara model RTG dengan model regresi linier berganda pada taraf nyata 0.05 . Kemudian Tabel 2 merupakan perbandingan nilai $\mathrm{R}^{2}$ dan AIC pada kedua model. Dapat dilihat bahwa nilai $\mathrm{R}^{2} \mathrm{RTG}$ lebih besar dibanding regresi linier dan nilai AIC RTG lebih kecil dibanding regresi linier. Hal ini menunjukkan bahwa pada IR campak Provinsi DKI Jakarta, model RTG yang didapat lebih baik digunakan dibanding model regresi linier berganda. 
Tabel II

PERBANDINGAN $\mathrm{R}^{2}$ DAN AIC

\begin{tabular}{lcc}
\hline \multicolumn{1}{c}{ Model } & $R^{2}$ & AIC \\
\hline Regresi Linier Berganda & $38.84 \%$ & 606.187 \\
RTG & $61.03 \%$ & 585.452 \\
\hline
\end{tabular}

\section{SIMPULAN DAN SARAN}

\section{A. Simpulan}

IR campak balita di kecamatan Provinsi DKI Jakarta menunjukkan pola yang cenderung acak dan beragam karena disebabkan oleh adanya pengaruh efek spasial yaitu heterogenitas spasial. Pemodelan dengan regresi terboboti geografis (RTG) lebih baik dalam mengatasi heterogenitas spasial karena mampu memberikan nilai $\mathrm{R}^{2}$ yang lebih besar dan nilai AIC yang lebih kecil dibanding dengan pemodelan regresi linier berganda. Setiap kecamatan di Provinsi DKI Jakarta mempunyai model persamaan dugaan penderita campak yang berbeda sehingga menghasilkan 42 model lokal. Kemudian, peubah penjelas yang berpengaruh signifikan terhadap IR campak pada balita adalah persentase cakupan imunisasi campak (X1), total curah hujan tahunan (X4), dan persentase banyaknya balita (X5).

\section{B. Saran}

Saran dari penelitian ini adalah melakukan penambahan peubah penjelas signifikan yang mampu memengaruhi IR campak pada balita sehingga didapatkan model yang lebih baik. Peubah-peubah tersebut adalah peubah sosial dan peubah cakupan vaksinasi ditahun-tahun sebelumnya (cakupan imunisasi campak booster). Kemudian untuk penelitian selanjutnya, disarankan untuk menambahkan amatan daerah tetangga DKI Jakarta seperti Tangerang, Depok dan Bekasi dalam memperhitungkan pengaruh daerah tetangga DKI Jakarta terhadap IR di daerah perbatasan DKI Jakarta.

\section{DAFTAR PUSTAKa}

Abdullatif, I. (2012). Analisis Spasial Kejadian Campak di Kota Administrasi Jakarta Timur Tahun 2008-2010. Depok (ID): Universitas Indonesia.
Anselin, L. (1988). Spatial Econometrics : Methods and Models. Netherlands (NLD): Kluwer Academic Publishers.

Brunsdon, C., A. S. Fotheringham, and M. Charlton (1999). Some notes on parametric significance tests for geographically weighted regression. Journal of Regional Science 39(3), 497524.

Draper, N. R. and H. Smith (1992). Analisis Regresi Terapan Edisi Kedua. Jakarta (ID): Gramedia Pustaka Utama.

Fotheringham, A. S., C. Brundson, and M. Charlton (2002). Geographically Weighted Regression : The Analysis of Spatially Varying Relationships. Chichester (GB): John Wiley and Sons.

Gujarati, D. N. (2004). Basic Econometrics Fourth Edition. New York (US): The McGraw-Hill Companies.

Lee, J. and D. W. S. Wong (2001). Statistical Analysis with Archview GIS. Canada (CA): John Wiley and Sons, Inc.

WHO (2017). Immunization, Vaccines and Biological: Measles. Geneva (CHE): WHO. 